Article

\title{
Credit Constraint, Credit Adjustment, and Sustainable Growth of Farmers' Income
}

\author{
Xiaohua Wang ${ }^{1}$, Meilan Chen ${ }^{2}$, Xi He ${ }^{1}$ and Fangfang Zhang ${ }^{3, *}$ \\ 1 College of Economics and Management, Southwest University, Chongqing 400715, China; \\ wangxiaohua@swu.edu.cn (X.W.); hx951007@swu.edu.cn (X.H.) \\ 2 International Business School, Guangdong University of Finance and Economics, Guangzhou 510320, China; \\ meilanchen2018@gmail.com \\ 3 Department of Accounting, Wenzhou Business College, Wenzhou 325035, China \\ * Correspondence: zhangfangfang1105@gmail.com; Tel.: +86-577-8659-9957
}

Received: 25 October 2018; Accepted: 20 November 2018; Published: 26 November 2018

check for updates

\begin{abstract}
Research on financial theory and practice has shown that the development of transition economies generally faces two major challenges. First, the less developed regions face more severe financial repression, which leads to imbalanced and unsustainable development of regional economies. Second, farmers face different credit constraints because of their productivity differences, which can further polarize the internal inequality of their income. Based on cross-sectional data of 2037 counties in 30 provinces of China in 2010, this paper employs quantile regression to investigate the relationships among credit constraints, credit adjustment, and the sustainable growth of farmers' income. Our results confirm that rural residents generally face credit constraints, and there are significant stratified differences in the impact of farmer credit on farmers' income. Farmers with higher income are more likely to obtain bank credit and continue to grow their income, while farmers with lower income are more likely to fall into the "vicious circle of poverty" because of their lack of capital accumulation. Therefore, to promote more fair and sustainable growth of farmers' income, it is important to increase the credit available to farmers. Furthermore, it is critical to promote healthy competition among county financial institutions and accelerate the establishment of inclusive financial systems. This can ultimately help ensure sustainable development of agriculture and rural economy.
\end{abstract}

Keywords: credit constraint; credit regulation; sustainable growth of farmers' income; sustainable development

\section{Introduction}

Sustainability addresses environmental and socioeconomic issues affecting current and future generations [1,2]. It is a way to understand the world as a complex interactive system among economic, social, environmental, and political systems [3,4]. County or rural economy is the basic functional unit of the national economy in many countries. Hence, sustainable development of county economy is crucial. However, county economy has been the weakest link many countries' economic development, as it has been imbalanced, uncoordinated, and unsustainable in many regions. To improve county economy, a key is to promote fast, stable, and sustainable growth of farmers' income, which requires the accumulation of financial capital for farmers. However, it is estimated that the amount of funds financed through various channels flowing from rural to urban areas has reached one trillion yuan in China. On average, the amount of outflow funds from each county has been more than 300 million yuan every year since the late 1990s [5]. Arguably, the most important reason lies in the financial system in China, which has been dominated by large state-owned commercial banks. This financial system is oriented toward city, industry, and commerce. It also favors large projects and corporations. 
This has led to long-term difficulty in securing loans among households and small and medium-sized enterprises in rural areas. Hence, checks and balances within government institutions are necessary to constrain the government from abusing its power, otherwise those political elite who tend to interpret and enforce them in ways that favor their interests over those of the masses will prevail [6]. Therefore, for financial resources that are not exclusive by the elites, the government must effectively regulate the credit resources and build an inclusive financial system to let more groups enjoy the benefits of financial development.

Since the mid-20th century, many economists have analyzed the positive roles that agriculture loans, farmers' loans, and fiscal expenditure can play in agricultural and rural development in developing countries [7-11]. Nurkse [7] argued that countries are poor partly because of a lack of adequate capital and equipment, which might be due to a lack of incentive to invest or a low capacity to save. Therefore, the author put forward the proposition "A country is poor because it's poor." Meanwhile, some studies have also discussed potential mechanisms by which governments can promote rural development through financial and fiscal instruments [12-16]. Mosley [17] pointed out that microfinance appears to be successful at helping those close to the poverty line and is relatively cheap, but ineffective at reducing extreme poverty. Matin et al. [18] concluded that the development of rural financial products and services should satisfy customers' preferences in order to contribute more to rural households' income. Fan et al. [19] estimated the agriculture expenditure of 30 sub-Saharan African countries needed to fulfill their annual goal of eradicating poverty by 2015 . They also argued for allocating financial resources to influence agriculture expenditure directly and indirectly.

More recently, Jayne and Boughton [20] showed that agriculture investment has to increase to maintain the sustainable development of rural areas. Furthermore, relevant policies are required to encourage private capital to flow into rural areas in order to improve rural financial services. Adetiloye [21] found that the provision of financial credit to the agricultural sector has not grown relative to the economy in Nigeria. Weber and Musshoff [22] demonstrated that rural household loans enhance farmers' investment and operating abilities in agriculture mainly by traditional capital approaches (including building up their ability to invest and manage), which contributes to increased agricultural output and farmers' income. Gao et al. [23] studied the effects of China's fiscal and financial support for agriculture based on provincial panel data employing the spatial panel econometric method. Their results showed that the enhancement of fiscal and financial support in 2004 has directly affected improvements in agriculture, but the spatial spillover effects have changed from positive to negative. Karlan et al. [24] noted that investment decisions of small-scale farmers in developing countries are largely affected by their financial environment. Binding credit market constraints and incomplete insurance can prevent investment from flowing into activities with high expected profits. Khandker and Koolwal [25] showed that supply-side credit constraints significantly lower crop income. Maitra et al. [26] implemented a trader-agent-intermediated lending program and a group-based lending program in randomly selected villages in West Bengal, India. They found that the former program increased production of the leading cash crop by $27 \%$ and farm incomes by $22 \%$, but the latter had insignificant effects. Adjognon et al. [27] found that the use of traditional credit, formal or informal, is extremely low. Instead, farmers primarily finance their input purchases with cash from nonfarm activities and crop sales. Beaman et al. [28] employed a two-stage loan and grant experiment and found that returns to capital were higher for farmers who borrowed than those who did not. Lacalle-Calderon et al. [29] found not only that microfinance significantly reduced the incidence and depth of poverty, but also that this effect differed across different poverty levels (quantiles).

Microfinance has become a buzzword in the credit markets as an effective tool for poverty reduction and socioeconomic development [29-38]. As shown in the literature, microfinance can have a significantly positive impact on poverty reduction. This is because microfinance institutions can provide microloans to farmers, women, or families in remote areas and vulnerable groups, and this can help reduce their financial exclusion [29-38]. The poverty reduction effects of microfinance include income improvement [25,35,39-43] and reduced financial vulnerability [40,44-49]. Hassan 
and Choudhury [35] found that collective actions through Islamic microfinance groups actually helped increase environmental awareness and improve the economic situations of their members. Samer et al. [37] examined the role of Amanah Ikhtiar Malaysia (AIM), Malaysia's largest microcredit organization, in household income. They found that AIM had a positive impact on the household income of women borrowers who spent three years in the scheme as compared to new borrowers. Miled et al. [38] showed that microfinance loans per capita are negatively associated with poverty gap (which measures the depth of poverty) and squared poverty gap (which measures the severity of poverty), implying that microfinance institutions benefit not just the poor but also the poorest. Nukpezah and Blankson [43] examined microfinance intervention for rural poverty reduction in Ghana by surveying 100 rural women farmer-entrepreneurs. They found that microfinance interventions that emphasize both credit provision and social intermediation improve credit access and business performance, and contribute to a higher standard of living for female farmer-entrepreneurs and their families.

World poverty is largely concentrated in agrarian societies with potential for agricultural productivity growth [50]. However, developing this potential cannot be separable from the input and effective allocation of its financial resources. Accordingly, many developing countries are competing to promote microcredit in their financial reform policies. Indeed, if microcredit can provide better access to institutional credit, it can help rural households manage risks and acquire inputs, including technology, to modernize agriculture and improve farm/nonfarm linkages [25]. Otherwise, microfinance may be unable to achieve poverty reduction [51-54] because of possible high interest rates, insufficient loans, unproductive use of loans, or even corruption and poor skills of microfinance institution staff [54]. Obviously, severe financial repression still exists in rural and poverty-stricken areas. Hence, the impact of microcredit on poverty alleviation is still unclear and varies from one country to another and from urban to rural areas [37].

Poverty is a concept that applies to all humans, and more seriously to people in the developing world [55]. As the largest developing country in the world, China has many farmers and a large poor population. However, it is undeniable that China has contributed greatly to alleviating global poverty and improving farmers' incomes, and its experience could be valuable for other developing countries to learn from. For example, Chinese farmers' average income rose from USD 85 in 1978 to USD 1991 in 2017. Therefore, this paper chooses China as its data source and case study.

With the acceleration of financial reform and growing attention on rural areas, the study of rural finance has been separated from traditional studies. Its focus has moved from the initial perspective of commercial transformation in rural financial institutions to rural credit and financial repression faced by rural households, and financial constraints and institutional issues in rural credit markets. However, there still exist serious financial repression and credit constraints in rural areas, and they hinder the sustainable development of agriculture and farmers' income [56].

In terms of research, little has been done regarding how credit constraints and credit adjustments impact the sustainable growth of farmers' income at the county level. Thus, in this paper, one of our main research objectives is to find out whether there is financial repression in China's county economy. If there is, are there any significant differences in financial repression for farmers at different income levels? Does financial repression intensify internal inequality in rural residents' income? Can the government help farmers through effective credit adjustment and promote the sustainable growth of their income? To answer these questions, we need to incorporate various factors, such as rural financial institutions, financial markets, and financial regulations. Furthermore, we need to treat farmers as a heterogeneous group, as they have different levels of production efficiency and capital accumulation ability. Otherwise, the internal differences among farmers cannot be addressed. Therefore, in this paper, we obtain sample data on the county level in China from 2010 by selecting 2037 counties in 30 provinces. We study the internal unequal relationship between credit constraints and credit adjustment and farmers' income with quantile regression. At the same time, we investigate the possibility that capital accumulation and external financing ability transform farmers from "moral 
peasants" to "rational peasants." (During the literature review of farmers' production and investment behaviors, we found two different theories: the "rational farmers" theory, which is based on traditional economics and represented by Schultz [57] and Popkin [58], who believe farmers abide by the "rational investor principle" of income maximization and reasonably allocate various resources that they own (including credit resources). On the contrary, Chayanov [59] and Polanyi et al. [60], representing the "survival farmers" theory, incorporate social, historical, and cultural factors into the analysis of small farmers' economic behaviors. They argue that farmers' behavior tends to deviate from economic rationality. Scott [61], who proposed the "moral economy" proposition, has a similar viewpoint.) In particular, we study how the finance industry can promote sustainable growth of farmers' income.

\section{Theoretical Model and Research Hypotheses}

Generally, absolute equal distribution of wealth and income is harmful to economic growth sustainability, as levying taxes on the rich would lessen enthusiasm for investment and innovation. However, reducing wealth inequality could actually stimulate economic growth in the presence of credit constraint in the economy $[62,63]$. Therefore, the change of the relationship between inequality and growth indicates that finance can greatly impact the growth process [64].

Ownership and usage rights are separated in the credit market. For the rural economy, farmers' income and rural economic growth would increase if capital were distributed to more farmers evenly. More even distribution would be achieved when farmers with less capital borrow from those with more. Credit constraints would impede this borrowing and lending process, thus hindering farmers' income and rural economic development.

Next, we introduce credit constraint into a simple AK model to analyze the relationship between bank credit and increased farmers' income. First, assume that there exist $N$ farmers in the rural economy. At the beginning of period $t$, farmer $i$ owns $e_{i t}$ units of capital. Therefore, the total capital stock of the rural area in period $t$ is:

$$
K_{t}=\sum_{i=1}^{N} e_{i t}
$$

Second, assume that farmers have different production rates. This means that they will maintain inequality in capital acquisition and accumulation. Farmers with higher production rates can obtain more capital, so they can use more capital to keep increasing their income. The opposite is true for farmers with lower production rates. To better analyze the income inequality caused by different production rates under different credit constraints, we focus on the case of no diminishing marginal productivity for individual farmers. Moreover, we assume any credit multiplier is allowed. Hence, the production function of each farmer during period $t$ can be written as follows:

$$
y_{i t}=\tau_{i t} k_{i t}
$$

where a farmer's individual production rate is denoted by parameter $\tau$, which will be different for different farmers. It satisfies the following:

$$
\frac{\tau_{1 t}>\tau_{2 t}>\ldots>\tau_{i t}>\ldots>\tau_{m-1 t}>\tau_{m t}>\tau_{m+1 t}>\tau_{m+2 t}>\ldots>\tau_{i t}>\ldots>\tau_{N t}}{M P} \frac{1 \leq i \leq m-1, F H P}{m+1<i \leq N, F H P}
$$

where FHP represents farmers with higher productivity, MP represents marginal producer, and FLP represents farmers with lower productivity. Equation (3) indicates that with the constant increase of $i$, relevant farmers' production rate will reduce gradually and the credit constraint that farmers face will increase correspondingly. $\tau_{m t}$ indicates the productivity of a marginal producer $m$ during period $t$. On the other hand, with the gradual decrease of $i$, farmers' productivity gradually increases, and the credit constraints that they face are reduced. For simplicity, we assume that farmers with higher productivity are high-income farmers, and farmers with lower productivity are low-income 
farmers. Farmer $i$ during period $t$ will choose capital employment $k_{i t}$ to maximize his/her earnings, which is:

$$
\pi_{i t}=\tau_{i t} k_{i t}-r\left(k_{i t}-e_{i t}\right)
$$

subject to the credit constraint $k_{i t} \leq v e_{i t}$. Here, $r$ represents market interest rate.

When $\tau_{i t}>r$, the capital employment of farmers' income strictly increases, but the maximal capital amount that farmers can use is $v e_{i t}$. When $\tau_{i t}<r$, farmers would choose to lend their own capital to obtain capital that is higher than earnings obtained from production through their direct use of the capital. As a result, farmers are faced with higher credit constraints and will not accept loans for investment. Therefore, they will not employ any capital but simply lend the capital amount $e_{i t}$ that they own. Finally, when $\tau_{i t}=r$, farmers' income is completely independent of $k_{i t}$, because farmers are willing to employ any amount of capital within the interval $\left(0, v e_{i t}\right)$, and the credit behavior is likely to happen.

To maintain the balance in rural financial markets, total capital employment will inevitably equal the total capital stock $K_{t}$, which occurs when the equilibrium interest rate is equal to $\tau_{m t}$, the productivity of a marginal producer $m$. The case of $\tau_{i t}>r$ is applicable to all farmers with $i<m$, and the case of $\tau_{i t}<r$ is applicable to all farmers with $i>m$. The total capital usage will be equal to the marginal producer's capital usage amount plus the maximum capital amount that all producers can use in the case of $\tau_{i t}>r$, so the equilibrium condition is as follows (defining $e_{0}=0$, thus the sum term of the equilibrium of Equation (5) is meaningful when $m=1$ ):

$$
k_{m t}+v \sum_{0}^{m-1} e_{i t}=K_{t}
$$

As the marginal producer corresponds to the case of $\tau_{i t}=r$, the following is required:

$$
0 \leq k_{m t} \leq K v e_{m t}
$$

Thus, the rural financial market equilibrium requirement is as follows (to infer Equation (7), substitute $k_{m t}$ in Equation (6) with Equation (5), then divide the three terms in this inequation by the credit multiplier $v$, and finally add $\left.\sum_{0}^{m} e_{i t}\right)$ :

$$
\sum_{0}^{m-1} e_{i t} \leq K_{t} / v \leq \sum_{0}^{m} e_{i t}
$$

Furthermore, what if the credit constraint increases or the credit incentive reduces, i.e. when credit multiplier $v$ is lower? First, assume that farmers with maximal productivity have no surplus borrowing capacity, which will occur when $e_{1} \leq K_{t} / v$ and $m>1$. When $v$ decreases, all farmers with efficiency higher than marginal producers have to reduce the amount of capital employment, while marginal producer $m$ will have more idle credit capital to borrow. Therefore, a lower-productivity farmer $i(i>m)$ will become a new marginal producer. More specifically, the gross output in the aforesaid circumstance can be written as follows:

$$
Y_{t}=\tau_{m t} k_{m t}+\sum_{0}^{m-1} \tau_{i t} k_{i t}=\tau_{m t} k_{m t}+v \sum_{0}^{m-1} \tau_{m t} e_{m t}
$$

where $Y_{t}$ represents the gross output. Together, Equation (8) and the market clearing Condition (5) lead to:

$$
Y_{t}=\tau_{m t} K_{t}+v \sum_{0}^{m-1}\left(\tau_{i t}-e_{m t}\right) e_{i t}
$$


Since the productivity of the $i$ th farmer is higher than that of the $m$ th farmer, the inequality $\tau_{i t}>\tau_{m t}$ is true and the following can be obtained:

$$
\frac{\partial Y_{t}}{\partial v}=\sum_{0}^{m-1}\left(\tau_{i t}-\tau_{m t}\right) e_{i t}>0
$$

Now consider the situation of $K_{t} / v<e_{1}$. This means the credit constraint is loose and the credit incentive is stronger. The extreme case is that all credit capital is employed by the farmers with maximal productivity, and the rural output can reach the maximum:

$$
Y_{\max }=\tau_{1} K_{t}
$$

In the two situations above $\left(K_{t} / v \geq e_{1}\right.$ and $\left.K_{t} / v<e_{1}\right)$, the growth rate can be expressed as:

$$
g=s\left(Y_{t} / K_{t}\right)-\delta
$$

where $g, s, \delta$ represents growth rate, saving rate and rate of depreciation, respectively.

It is worth noting that when there is a tightening of $v$ (monetary multiplier), credit capital that pursues profit and avoids risk often transfers to farmers with higher productivity from those with low productivity. Once the credit capital is excessively concentrated, it may aggravate the income gap among farmers and ultimately threaten the sustainable development of rural economies. To prevent this potential problem, the government may impose credit restrictions on high-income farmers, improve credit incentives for low-income farmers, and strive to promote the balanced allocation of credit capital among farmers. This will lead to inefficient use of some credit capital. However, this does not mean that any form of farmers' credit adjustment by the government will have little effect on reducing the income inequality among farmers. In fact, if the credit incentive of high-income farmers is excessive, it can result in a severe decrease in marginal revenue of credit capital for the investment of richer farmers. The government, with its leading role in some financial institutions, can move some remaining credit capital from the rich farmers to the poor ones facing serious credit constraints. In this way, the poor farmers will have the opportunity to expand production without impairing the economic efficiency of the rich ones. This can grow the poor farmers' income and enhance social welfare. In addition, if some credit capital is allocated to poor but highly productive farmers, it will also grow the income of the poor ones and reduce the income inequality among farmers.

Based on the discussions above, this paper proposes the following hypotheses:

Hypothesis 1. Due to differences in farmers' income, initial capital accumulation, and productivity, the loans that they are willing and able to get are different. Furthermore, the income increment effects of their loans are also different.

Hypothesis 2. The government can adjust some agricultural credits of financial institutions among farmers to reduce their income gap due to excessive imbalance of their credit marketization. This can promote farmers' income growth and sustainable development of the rural economy.

\section{Data and Research Method}

\subsection{Data}

The variables involved in this research include per capita net income of farmers, credit of rural households, fiscal expenditure, fixed asset investment in rural areas, rural employment rate, industrial structure, total power of agricultural machinery, and production of food and meat. These variables are all in terms of per capita value in order to eliminate the effects of gross population and its structure. 
We also did log processing on the data to avoid heteroscedasticity and muliticollinearity issues. The definitions, codes, and calculation methods of these variables are listed in Table 1.

Table 1. Definitions, codes, and calculation methods of the variables.

\begin{tabular}{|c|c|c|}
\hline Variable & Code & Calculation Method \\
\hline Per capita net income of farmers & FINC & Per capita net income of farmers in counties \\
\hline Credit of rural household per head & LOAN & $\begin{array}{l}\text { Farmers' loan balance in counties at the end of the } \\
\text { year/number of rural laborers }\end{array}$ \\
\hline Fiscal expenditure per head & FISCAL & $\begin{array}{l}\text { Counties' general budget expenditures of local } \\
\text { finance/total county population }\end{array}$ \\
\hline $\begin{array}{l}\text { Fixed asset investment in rural } \\
\text { areas per head }\end{array}$ & INVEST & $\begin{array}{l}\text { (Total investment in fixed assets in rural areas - } \\
\text { investment in fixed assets in urban areas)/number of } \\
\text { rural laborers }\end{array}$ \\
\hline Rural employment rate & REMP & $\begin{array}{l}\text { (Number of rural laborers / total population in } \\
\text { county) } \times 100 \%\end{array}$ \\
\hline Industrial structure & STRU & $\begin{array}{c}\text { (Gross output of primary industry/gross domestic } \\
\text { product }(\mathrm{GDP})) \times 100 \%\end{array}$ \\
\hline $\begin{array}{l}\text { Total power of agricultural } \\
\text { machinery }\end{array}$ & POWER & $\begin{array}{l}\text { Total agricultural machinery power in } \\
\text { county/number of rural laborers }\end{array}$ \\
\hline Food output per head & FOOD & Total county grain output/number of rural laborers \\
\hline Meat output per head & MEAT & Total county meat output/number of rural laborers \\
\hline
\end{tabular}

The data on credit of rural household comes from the rural financial service section of the China Banking Regulatory Commission website (http:/ / www.cbrc.gov.cn/index.html). The atlas collects basic economic and financial data from 2861 counties in 31 provinces in China and has full details of branch networks and coverage and distribution of deposits and loans in different cities and counties of the banking industry. The data of the other variables are from the main statistical indicators of county units of China's Regional Economic Statistical Yearbook 2011 [65] and China County (City) Social Economic Statistical Yearbook 2011 [66]. All data were cleaned after singular data were eliminated and missing data were deleted or interpolated. The missing parts of other variables were also interpolated using statistics in the China Rural Financial Services Distribution Atlas in 2010, which is published by the China Banking Regulatory Commission. With 2037 counties (cities) in 30 Chinese provinces taken as the samples, the relationships among credit constraints, credit adjustments, and internal income inequality of farmers were analyzed by quantile regression. The summary statistics of these variables are presented in Table 2.

Table 2. Summary statistics of the variables.

\begin{tabular}{cccccccc}
\hline Code & Obs & Mean & Std. Dev & Min & Max & Skewness & Kurtosis \\
\hline FINC & 2037 & 8.5500 & 0.4379 & 6.5367 & 9.9081 & -0.2500 & 3.2298 \\
LOAN & 2037 & 7.8914 & 2.0228 & -0.7441 & 13.118 & -3.0474 & 12.427 \\
FISCAL & 2037 & 8.1152 & 0.5692 & 6.5975 & 10.579 & 0.8791 & 4.2584 \\
INVEST & 2037 & 7.9605 & 2.3784 & -0.3488 & 14.707 & -2.117 & 7.8668 \\
REMP & 2037 & 3.9710 & 0.2916 & -0.6342 & 4.6137 & -9.4875 & 124.20 \\
STRU & 2037 & 2.9321 & 0.6901 & -2.8917 & 4.3787 & -1.4459 & 7.3887 \\
POWER & 2037 & 0.5092 & 0.7876 & -2.8965 & 5.7959 & 0.3127 & 4.8682 \\
FOOD & 2037 & 6.8330 & 1.1370 & -2.3461 & 11.868 & -2.5994 & 18.282 \\
MEAT & 2037 & 5.0756 & 0.7917 & -3.2182 & 9.3849 & -0.12418 & 6.5528 \\
\hline
\end{tabular}




\subsection{Research Method}

The parameter of ordinary least squares (OLS) regression is the marginal effect the independent variable has on the dependent variable's conditional expectation. Therefore, the decomposition results can only describe the concept of "average". Consequently, different effects of farmer household credit and other contributing factors in various intervals could not be considered. However, more random quantiles could be selected to conduct parameter estimation in the quantile regression. Thus, we adopted quantile regression to examine how rural household credit and other contributing factors impact the distribution of rural household income levels.

Quantile regression was first proposed by Koenker and Bassett [67]. In theory, quantile regression is a type of regression method based on the conditional distribution of variable $y$, which is a linear function of the independent variable $x$. It is an extension and robust check of OLS regression. Different quantile functions can be obtained at different quantile levels. All the conditional distribution paths of $y$ on $x$ can be attained with quantile values ranging from 0 to 1 using quantile regression as a cluster of curves instead of a single curve with OLS regression. Therefore, quantile regression is a good choice when data points in different locations are desirable.

Assume that the general $q$ quantile $y_{q}(x)$ of the conditional distribution $y \mid x$ is a linear function of $x$. That is:

$$
y_{q}\left(x_{i}\right)=x_{i}^{\prime} \beta_{q}
$$

where $\beta_{q}$ is the coefficient of quantile regression, and the estimator $\hat{\beta}_{q}$ can be defined with the following minimization problem:

$$
\min \sum_{i: y_{i} \geq x_{i}^{\prime} \beta_{q}}^{n} q\left|y_{i}-x_{i}^{\prime} \beta_{q}\right|+\sum_{i: y_{i}<x_{i}^{\prime} \beta_{q}}^{n}(1-q)\left|y_{i}-x_{i}^{\prime} \beta_{q}\right|
$$

If $q=0.5$, it is the median regression, where the objective function can be simplified as:

$$
\min \sum_{i=1}^{n 2}\left(\left|y_{i}-x_{i}^{\prime} \beta\right|\right.
$$

Clearly, the quantile regression is less affected by extreme values and its results are more stable than those obtained from the mean regression (OLS). The use of quantile regression can better estimate the direction and strength of the impact of household credit and other factors on farmers' income levels.

\section{Analysis of Empirical Results}

In this paper, we use Stata 12.0 to conduct quantile regression analysis in order to better investigate the different impacts of rural household credit and other factors on farmers' income with different quantile conditions in different areas. As quantiles can fully depict the distribution of income, and the regression of quantiles of income distribution as explained variables can visually show the marginal returns of the factors at different income levels, a quantile regression result of farmers' income determining equation will be obtained in this paper. Following the approach proposed by Wang et al. (2014), we selected five quantiles: QR_10, QR_25, QR_50, QR_75, and QR_90.

According to the OLS regression results reported in the second column of Table 3, the elasticity coefficient of rural household credit is significantly positive for rural per capita net income. This means that rural household credit could improve farmers' income. However, the decomposition results of OLS regression can only describe the averages. Consequently, different effects of farmer household credit and other contributing factors in various intervals could not be considered. Thus, this paper uses quantile regression to analyze the robustness of the result that rural household credit could improve farmers' income. It can be seen from Table 3 that the elasticity coefficient of rural household credit is significantly negative at QR_10, insignificant at QR_25 and QR_75, and significantly positive at QR_50 and QR_90. Thus, it first increases and then decreases when the condition distribution moves from low 
to high: the elasticity values are $-0.0107,0.0001,0.0137,0.0097$, and 0.0156 at QR_10, QR_25, QR_50, QR_75, and QR_90, respectively. This shows that farmers with different incomes could face different capital restraints, and they are influenced by rural household credit differently. Hence, rural household credit does not help households with the lowest income, which is obviously not conducive to the relief of rural poverty. Also, the elite capture mechanism is widely distributed over the rural credit market in China, leading to potential structure distortions, function dislocation, and target deviation. This conclusion is different from that of Khandker [29] and Lacalle-Calderon et al. [31], who found that microfinance benefits those in extreme poverty more than those in moderate poverty, suggesting that microcredit reaches and benefits even the poorest individuals.

Table 3. Factors affecting farmers' income based on quantile regression.

\begin{tabular}{|c|c|c|c|c|c|c|}
\hline \multicolumn{7}{|c|}{ Explained Variable: FINC (Rural per Capita Net Income) } \\
\hline LOAN & $0.0103^{* *}$ & $-0.0107^{* *}$ & 0.0001 & $0.0137^{* * *}$ & 0.0097 & $0.0156^{* * *}$ \\
\hline FISCAL & $-0.1320^{* * *}$ & $-0.2658^{* * *}$ & $-0.2733^{* * *}$ & $-0.2117^{* * *}$ & $-0.0751^{* * *}$ & $0.0882 * * *$ \\
\hline Budget expenditure per head & $(0.000)$ & $(0.000)$ & $(0.000)$ & $(0.000)$ & $(0.002)$ & $(0.004)$ \\
\hline Fixed asset investment in rural per head & $(0.002)$ & $(0.001)$ & $(0.006)$ & $(0.011)$ & $(0.220)$ & $(0.845)$ \\
\hline REMP & $0.2753 * * *$ & $0.5705^{* * *}$ & $0.3279^{* * *}$ & $0.2206^{* *}$ & $0.1826^{* * *}$ & $0.1656 *$ \\
\hline Rural employment rate & $(0.000)$ & $(0.000)$ & $(0.000)$ & $(0.000)$ & $(0.001)$ & $(0.086)$ \\
\hline POWER & $0.0693^{* * *}$ & $0.0992^{* * *}$ & $0.0817^{* * *}$ & $0.0572 * * *$ & $0.0379 * *$ & $0.0527 * *$ \\
\hline Total power of agricultural machinery & $(0.000)$ & $(0.001)$ & $(0.000)$ & $(0.000)$ & $(0.010)$ & $(0.015)$ \\
\hline Food output per head & $(0.300)$ & $(0.232)$ & $(0.128)$ & $(0.009)$ & $(0.074)$ & $(0.183)$ \\
\hline MEAT & $0.1375^{* * *}$ & $0.1947^{* * *}$ & $0.2092^{* * *}$ & $0.1992^{* * *}$ & $0.1106^{* * *}$ & 0.0283 \\
\hline Food output per head & $(0.000)$ & $(0.000)$ & $(0.000)$ & $(0.000)$ & $(0.000)$ & $(0.152)$ \\
\hline$C$ & $7.9584^{* * *}$ & $6.7319^{* * *}$ & $8.1405^{* * *}$ & $8.5802 * * *$ & $8.4187^{* * *}$ & $7.5185^{* * *}$ \\
\hline$c$ & $(0.000)$ & $(0.000)$ & $(0.000)$ & $(0.000)$ & $(0.000)$ & $(0.000)$ \\
\hline Pseudo $R^{2}$ & - & 0.2908 & 0.3386 & 0.3192 & 0.2676 & 0.2854 \\
\hline $\operatorname{Adj} R^{2}$ & 0.4033 & & & & & \\
\hline$F$ value & $108.34^{* * *}$ & & & & & \\
\hline
\end{tabular}

Note: ${ }^{*}, * *$, and ${ }^{* * *}$ signify $10 \%, 5 \%$, and $1 \%$ significance level, respectively, and the numerical values inside the parentheses represent $p$ values. OLS, ordinary least squares.

Farmers at the lowest income level may be unable to fulfill their basic production and living consumption demand. Moreover, they cannot secure external funding, so the elasticity coefficient of rural household credit is significantly negative at QR_10. Farmers at the lower-middle income level may still be unable to satisfy basic production and living requirements with their own capital, and they have difficulty obtaining commercial financial resources. However, they are clearly better off than farmers at the lowest income level, so their elasticity coefficient of rural household credit is positive but not significant at QR_25. Farmers with income at the middle level could obtain capital more easily due to their own capital accumulation and better ability to obtain external funding. The capital requirement for this type of farmer is mainly due to production needs, so their elasticity coefficient of rural household credit is significantly positive at QR_50. Farmers at the higher-middle income level are able to satisfy the production and living requirements quite well with their own capital, and they have better external financing ability. Therefore, their elasticity coefficient of rural household credit is positive at QR_75. However, it is smaller than those at QR_50 and QR_90. This is probably because farmers at the high-middle income level need fewer external credit resources than farmers at other income levels. Finally, farmers at the highest income level are able to finance through formal financial 
institutions and are the most capable of obtaining capital. Consequently, their elasticity coefficient of rural household credit is significantly positive and the largest at QR_90.

Our results show that the fiscal expenditure of a county government has a significant repressive impact on farmers' income at all quantiles except for QR_90. The absolute value of the elasticity coefficient decreases progressively as the condition distribution moves from low to high. Farmers' income at QR_90 has a significant positive correlation with fiscal expenditure. This indicates that it is more difficult for lower-income farmers to improve their income because of insufficient government expenditure in county areas. The reasons are twofold. First, many counties in China tend to focus their limited fiscal resources on building "luxury" cities, "beautiful" cities, or "modern" cities. As a result, basic infrastructure construction and production and living conditions in rural areas have been ignored. This is especially true for many poor counties. Second, fiscal spending is a form of exogenous mechanism, which has limited impact on economic development in the long term. Moreover, it may not be good for the development of agriculture and farmers, as extended and repeated fiscal expenditure could trigger the subsidy dependence issue in the county economy. Additionally, insufficient funds and imperfect relevant policies could lead to irrational capital allocation with a large number of poor farmers. Fiscal spending would not work well as an exogenous force except for the poor, who are in urgent need of production and living funds.

Moreover, we can draw the following conclusions from our empirical analysis. First, the elasticity coefficients of rural employment rate (REMP) and total power of agricultural machinery (POWER) are significantly positive at all quantiles examined. The elasticity coefficient of REMP always decreases, while that of POWER first decreases and then increases. Second, the elasticity coefficients of fixed asset investment (INVEST) and food output (FOOD and MEAT) are all positive at quantiles examined. The elasticity coefficient of INVEST appears significant at the first three quantiles and then decreases as the condition distribution moves from low to high. The elasticity coefficient of FOOD is only positive at QR_50 and QR_70 and decreases progressively as the condition distribution moves from low to high (except at QR_90). The elasticity coefficient of MEAT is positive at all quantiles except for QR_90 and demonstrates a J-curve tendency as the condition distribution moves from low to high. Third, the elasticity coefficient of industrial structure (STRU, the ratio of the first industry) is significantly negative at all quantiles and exhibits a U-curve tendency as the condition distribution moves from low to high.

Although we explicitly control as many variables as possible in the regression, there is still a possible endogeneity issue between rural household credit and per capita net income. One possibility is that a factor such as the county's fixed effect simultaneously leads to higher rural household credit and higher rural per capita net income, which results in a spurious correlation between the two. In order to solve the potential endogeneity issue, we used two-stage least squares (2SLS) estimation. A proper instrument needs to satisfy relevance and exclusion conditions. Based on the above reasons and data availability, we selected one plausible instrument for our 2SLS estimation, the average rural household credit of all the counties in the same province (Province-average LOAN). Obviously, the average credit of rural household per head in the province is likely to correlate with the credit of rural household per head of a county. Meanwhile, we have no reason to believe that such average credit of rural household per head in the province would influence the rural per capita net income of a specific county; hence, we expect these measures to be uncorrelated with the error term.

Table 4 reports the results from the 2SLS estimation. The first column shows the first stage with the dependent variable LOAN. As expected, the instrumental variable is positively related to county-level credit of rural household per head and is statistically significant at the $1 \%$ level. The next five columns show the second-stage regression results by quantile regression. After controlling the potential endogeneity, LOAN continues to be negatively correlated with rural per capita net income at QR_10 and positively correlated with rural per capita net income at QR_25, QR_50, QR_75, and QR_90. 
Table 4. Factors affecting farmers' income based on quantile regression: two-stage least squares (2SLS) estimation.

\begin{tabular}{|c|c|c|c|c|c|c|}
\hline & 1st Stage & & & 2nd Stage & & \\
\hline & OLS & QR_10 & QR_25 & QR_50 & QR_75 & QR_90 \\
\hline Explained Variable & LOAN & \multicolumn{5}{|c|}{ FINC (Rural per Capita Net Income) } \\
\hline $\begin{array}{l}\text { Instrumented LOAN } \\
\text { Credit of rural household per head }\end{array}$ & & $\begin{array}{l}-0.0043 * * \\
(0.025)\end{array}$ & $\begin{array}{l}0.0025^{*} \\
(0.085)\end{array}$ & $\begin{array}{l}0.0055^{* *} \\
(0.019)\end{array}$ & $\begin{array}{l}0.0021 \\
(0.157)\end{array}$ & $\begin{array}{c}0.0107^{* * *} \\
(0.000)\end{array}$ \\
\hline $\begin{array}{l}\text { Province-average LOAN } \\
\text { Credit of rural household per head }\end{array}$ & $\begin{array}{l}0.2815^{* * *} \\
(0.000)\end{array}$ & & & & & \\
\hline $\begin{array}{c}\text { FISCAL } \\
\text { Budget expenditure per head }\end{array}$ & $\begin{aligned}-0.0905^{* * *} & (0.000)\end{aligned}$ & $\begin{array}{l}-0.1721^{* * *} \\
(0.000)\end{array}$ & $\begin{aligned}-0.1397^{* * *} & (0.000)\end{aligned}$ & $\begin{array}{l}-0.1282 * * * \\
(0.000)\end{array}$ & $\begin{aligned}-0.1223^{* * *} & (0.000)\end{aligned}$ & $\begin{array}{l}-0.1119 * * * \\
(0.000)\end{array}$ \\
\hline $\begin{array}{c}\text { INVEST } \\
\text { Fixed asset investment in rural per } \\
\text { head }\end{array}$ & $\begin{array}{c}0.0077^{* *} \\
(0.046)\end{array}$ & $\begin{array}{c}0.0122 * * * \\
(0.000)\end{array}$ & $\begin{array}{l}0.0096^{* * *} \\
(0.000)\end{array}$ & $\begin{array}{l}0.0112 * * * \\
(0.000)\end{array}$ & $\begin{array}{l}0.0109 * * * \\
(0.000)\end{array}$ & $\begin{array}{c}0.0153^{* * *} \\
(0.000)\end{array}$ \\
\hline $\begin{array}{c}\text { REMP } \\
\text { Rural employment rate }\end{array}$ & $\begin{array}{l}0.2807^{* * *} \\
(0.000)\end{array}$ & $\begin{array}{l}0.2823^{* * *} \\
(0.000)\end{array}$ & $\begin{array}{l}0.2280^{* * *} \\
(0.000)\end{array}$ & $\begin{array}{l}0.2160 * * * \\
(0.000)\end{array}$ & $\begin{array}{l}0.2202^{* * *} \\
(0.000)\end{array}$ & $\begin{array}{l}0.2766^{* * *} \\
(0.000)\end{array}$ \\
\hline $\begin{array}{c}\text { POWER } \\
\text { Total power of agricultural } \\
\text { machinery }\end{array}$ & $\begin{array}{l}0.0513^{* * *} \\
(0.000)\end{array}$ & $\begin{array}{c}0.0689 * * * \\
(0.000)\end{array}$ & $\begin{array}{c}0.0701 * * * \\
(0.000)\end{array}$ & $\begin{array}{c}0.0903^{* * *} \\
(0.000)\end{array}$ & $\begin{array}{l}0.0888^{* * *} \\
(0.000)\end{array}$ & $\begin{array}{l}0.0863 * * * \\
(0.000)\end{array}$ \\
\hline $\begin{array}{c}\text { STRU } \\
\text { Industrial structure }\end{array}$ & $\begin{array}{l}-0.2364^{* * *} \\
\quad(0.000)\end{array}$ & $\begin{array}{l}-0.2897^{* * *} \\
(0.000)\end{array}$ & $\begin{array}{l}-0.2943^{* * *} \\
(0.000)\end{array}$ & $\begin{array}{l}-0.2962 * * * \\
(0.000)\end{array}$ & $\begin{array}{l}-0.2982 * * * \\
(0.000)\end{array}$ & $\begin{array}{l}-0.3300 * * * \\
(0.000)\end{array}$ \\
\hline $\begin{array}{c}\text { FOOD } \\
\text { Food output per head }\end{array}$ & $\begin{array}{l}-0.0064 \\
(0.609)\end{array}$ & $\begin{array}{c}0.0344 * * * \\
(0.000)\end{array}$ & $\begin{array}{c}0.0264 * * * \\
(0.000)\end{array}$ & $\begin{array}{c}0.0073^{* *} \\
(0.024)\end{array}$ & $\begin{array}{l}-0.0108 * * \\
(0.030)\end{array}$ & $\begin{array}{l}-0.0224 * * * \\
(0.000)\end{array}$ \\
\hline $\begin{array}{c}\text { MEAT } \\
\text { Food output per head }\end{array}$ & $\begin{array}{c}0.1450 * * * \\
(0.000)\end{array}$ & $\begin{array}{c}0.1453^{* * *} \\
(0.000)\end{array}$ & $\begin{array}{c}0.1388^{* * *} \\
(0.000)\end{array}$ & $\begin{array}{c}0.1327^{* * *} \\
(0.000)\end{array}$ & $\begin{array}{c}0.1292 * * * \\
(0.000)\end{array}$ & $\begin{array}{c}0.1454^{* * *} \\
(0.000)\end{array}$ \\
\hline $\mathrm{C}$ & $\begin{array}{c}5.7000 * * * \\
(0.000)\end{array}$ & $\begin{array}{l}7.9288^{* * *} \\
(0.000)\end{array}$ & $\begin{array}{l}8.0764^{* * *} \\
(0.000)\end{array}$ & $\begin{array}{c}8.0961^{* * *} \\
(0.000)\end{array}$ & $\begin{array}{c}8.2390 * * * \\
(0.000)\end{array}$ & $\begin{array}{c}8.0567^{* * *} \\
(0.000)\end{array}$ \\
\hline $\operatorname{Adj} R^{2}$ & 0.3811 & & & & & \\
\hline$F$ value & $148.93^{* * *}$ & & & & & \\
\hline
\end{tabular}

Note: ${ }^{* * *}$, and ${ }^{* * *}$ signify $10 \%, 5 \%$, and $1 \%$ significance level, respectively, and the numerical values inside the parentheses represent $p$ values.

Based on the above empirical results, we can conclude that economic productivity due to increasing rural household credit is not necessarily low, especially when credit input for farmers at the lower-middle income level has been raised. Therefore, financial institutions can greatly help develop county economy, improve farmers' income, and achieve sustainable development. Rural financial service would inevitably face the divided supply problem of triplicity, including policy-based, commercial, and cooperation-based finance, for a long time in the future. Therefore, financial institutions should tailor their financial products to farmers based on their income levels to build an inclusive financial system. For farmers at the lowest and low-middle income levels, the national poverty alleviation fund and policy-based rural household loans could play a positive role. For farmers at the middle and high-middle levels of income, rational private credit and policy-based and certain commercial loans could play a joint role. For farmers at the highest level of income, financing can be provided mainly by commercial financial institutions. Our results show that neither "survival" nor "rational" fully describes the status quo for farmers in China's rural counties. This is because the former presents an overly pessimistic view of financial aid, while the latter demonstrates an overly optimistic view. Therefore, our research expands the perspectives of survival farmers and rational farmers proposed in previous research. Our results also demonstrate that the reasons farmers with low income are survival farmers are insufficient initial capital and the inability to finance externally. For this reason, we believe that once farmers obtain a certain amount of capital, they can gradually enhance their external financing ability. Moreover, as long as farmers can create a virtuous cycle of accumulating their own capital and utilizing external financing, the "moral peasant" will consequently evolve into the "rational peasant" to make the increase in farmers' income more sustainable. 


\section{Conclusions and Policy Recommendations}

It is important for county governments to allocate their limited fiscal and credit resources to rural areas to improve the capital supply to the rural economy, improve farmers' income, and achieve sustainable development. In this research, we conducted an empirical analysis of the contributing factors affecting farmers' income using quantile regression. We used cross-sectional data from 2037 counties of 30 provinces of China in 2010.

In this research, we obtained the following major results. First, the elasticity coefficient of rural household credit is significantly negative at QR_10, but positive at QR_25, QR_50, QR_75, and QR_90. Second, in general, farmers' income and county fiscal budgets have a significant positive correlation. Hence, there is a significant delamination in the influence of credit loans and fiscal expenditures on farmers' income. Rural household credit loans and fiscal expenditures tend to go to farmers with higher income, while farmers with lower income are often overlooked. Together with their own lack of capital accumulation, this may put poorer farmers into a poverty vicious cycle.

Thus, it is necessary to improve the relatively weak agricultural and rural economy and facilitate balanced and sustainable growth of farmers' income. To achieve these goals, for farmers at different income and productivity levels under different credit constraints, it is necessary to establish rural financial institutions with diverse and inclusive structures. Second, increased capital input, especially supporting funds for agriculture, is necessary to promote sustainable county economy and farmers' income growth. However, at the same time, this may lead to farmers' excessive dependency on the external funds provided by governments and financial institutions. This may actually make it more difficult to achieve sustainable development of farmers' income and rural economy.

Based on our analysis and results, we offer the following policy recommendations to facilitate improvement in farmers' sustainable income. First, competition among financial institutions in rural areas should be promoted in the long term. The restrictions in terms of the entry and share proportions of county banks should be relaxed, while the development of microcredit companies should be guided and promoted. To achieve a sustainable increase in farmers' income, community financial institutions can be established to serve small and micro business of rural residents. Meanwhile, it is important to create a good financial ecosystem to help commercial banks establish more branches, improve the competencies of county finance, improve the allocation mechanism of financial resources, and increase allocation efficiency. Furthermore, county financial institutions should open up the rural credit market, strengthen credit support for farmers with lower income, and accelerate the improvement of farmers' income. Second, the cooperation mechanism of fiscal and financial policies should be improved. Further improvement of rural credit and fiscal policies as well as the efficiency of fund usage should be pursued. The government should encourage rural households to improve production and guide financial institutions to provide more credit support for new production activities. Moreover, financial institutions should relax the traditional credit standards to recognize and satisfy the potential need in rural areas. Third, the government can raise the ratio of fiscal support for agriculture and improve the transfer payment to lower-income farmers. Also, the government should support the development of nonagricultural industries in counties with rural enterprises, as they have already become the main drivers for county economies. Last but not least, the government can help build "harmonious and complementary" relationships among rural households, government, and financial institutions in order to further expand the rural credit market. This can achieve better coordination and allocation of rural credit resources and fiscal funds to achieve more sustainable rural economies.

Although our study provides new macroeconomic evidence on the relationship between the growth of farmers' income and rural household credit, it may have some limitations. First, our data sample is still limited in scope, so future studies could obtain and analyze larger and more representative samples. With larger samples and/or more variables, future studies could test the robustness of our results in this paper. Second, due to the limitation of data availability, we cannot rule out the possibility of correlation rather than causation in this paper. In future research, it would be 
worthwhile to explicitly explore possible causation among credit constraint, credit adjustment, and the sustainable growth of farmers' income.

Author Contributions: X.W. prepared the entire research framework, managed the manuscript and results discussion; M.C. prepared the initial data; X.H. prepared the analysis check; F.Z. prepared for manuscript submission, interviews and surveys with professionals and robust check.

Funding: This research was funded by National Natural Science Foundation of China (Grant Number: 71773099), the Fundamental Research Funds for the Central Universities (Grant Number: SWU1809020), Major Projects of the National Social Science Fund (Grant Number: 18ZDA093), Natural Science Foundation of Zhejiang (Grant Number: LQ19G020002), and Social Science Planning Project of Wenzhou (Grant Number: 18wsk210).

Conflicts of Interest: The authors declare no conflict of interest.

\section{References}

1. Hopwood, B.; Mellor, M.; O’Brien, G. Sustainable development: Mapping different approaches. Sustain. Dev. 2010, 13, 38-52. [CrossRef]

2. Molina-Moreno, V.; Núñez-Cacho Utrilla, P.; Cortés-García, F.J.; Peña-García, A. The Use of Led Technology and Biomass to Power Public Lighting in a Local Context: The Case of Baeza (Spain). Energies 2018, 11, 1783. [CrossRef]

3. Ayoo, C. The age of sustainable development. Am. J. Agric. Econ. 2015, 98, 667-669. [CrossRef]

4. Scheel, C. Beyond sustainability. transforming industrial zero-valued residues into increasing economic returns. J. Clean. Prod. 2016, 131, 376-386. [CrossRef]

5. He, G. Promoting the Allocation of Financial Resources and Its Essential Elements to the Rural Areas. Manag. Adm. Rural. Coop. 2010, 3, 14-15.

6. Holcombe, R.G. Checks and Balances: Enforcing Constitutional Constraints. Economies 2018, 6, 57. [CrossRef]

7. Nurkse, R. The Problem of Capital Formation in Less-Developed Countries; Oxford University Press: Oxford, UK, 1953; Volume 33, pp. 1-337.

8. Gonzalez-Vega, C. Credit Rationing Behavior of Agricultural Lenders: The Iron Law of Interest Rate Restrictions; Department of Agricultural Economics and Rural Sociology (USA), ESO-Ohio State University: Washington, DC, USA, 1983. [CrossRef]

9. Bencivenga, V.R.; Smith, B.D. Financial intermediation and endogenous growth. Rev. Econ. Stud. 1991, 58, 195-209. [CrossRef]

10. Munnell, A.H. Policy watch: Infrastructure investment and economic growth. J. Econ. Perspect. 1992, 6, 189-198. [CrossRef]

11. Darrat, A.F. Are financial deepening and economic growth causally related? Another look at the evidence. Int. Econ. J. 1999, 13, 19-35. [CrossRef]

12. Hayami, Y.; Ruttan, V.W. Agricultural Development: An International Perspective; The Johns Hopkins Press: Baltimore, MD, USA, 1971.

13. Barro, R.J.; Sala-i-Martin, X. Public finance in models of economic growth. Rev. Econ. Stud. 1992, 59, 645-661. [CrossRef]

14. Tatom, J.A. Paved with good intentions: The mythical national infrastructure crisis. Policy Anal. 1993, 133, 1871-1879. [CrossRef]

15. Gramlich, E.M. Infrastructure investment: A review essay. J. Econ. Lit. 1994, 32, 1176-1196. [CrossRef]

16. Garcia-Mila, T.; McGuire, T.J.; Porter, R.H. The effect of public capital in state-level production functions reconsidered. Rev. Econ. Stat. 1996, 78, 177-180. [CrossRef]

17. Mosley, P. Microfinance and poverty in Bolivia. J. Dev. Stud. 2001, 37, 101-132. [CrossRef]

18. Matin, I.; Hulme, D.; Rutherford, S. Finance for the poor: From microcredit to microfinancial services. J. Int. Dev. 2002, 14, 273-294. [CrossRef]

19. Fan, S.; Johnson, M.; Saurkar, A.; Makombe, T. Investing in African Agriculture to Halve Poverty by 2015; International Food Policy Research Institute: Washington, DC, USA, 2008; pp. 42-43.

20. Jayne, T.S.; Boughton, D. What Kind of Agricultural Strategies Lead to Broad-Based Growth: Implications for Country-Led Agricultural Investment Programs. 2011. Available online: http:/ / citeseerx.ist.psu.edu/ viewdoc/summary?doi=10.1.1.224.7485 (accessed on 23 November 2018). 
21. Adetiloye, K.A. Agricultural financing in Nigeria: An assessment of the Agricultural Credit Guarantee Scheme Fund (ACGSF) for food security in Nigeria (1978-2006). J. Econ. 2012, 3, 39-48. [CrossRef]

22. Weber, R.; Musshoff, O. Is agricultural microcredit really more risky? Evidence from Tanzania. Agric. Financ. Rev. 2012, 72, 416-435. [CrossRef]

23. Yuandong, G.; Tao, W.; Wen, Y.; Xiaohua, W. A spatial econometric study on effects of fiscal and financial supports for agriculture in China. Agric. Econ. 2013, 59, 315-332. [CrossRef]

24. Karlan, D.; Osei, R.; Osei-Akoto, I.; Udry, C. Agricultural decisions after relaxing credit and risk constraints. Q. J. Econ. 2014, 129, 597-652. [CrossRef]

25. Khandker, S.R.; Koolwal, G.B. How has microcredit supported agriculture? Evidence using panel data from Bangladesh. Agric. Econ. 2016, 47, 157-168. [CrossRef]

26. Maitra, P.; Mitra, S.; Mookherjee, D.; Motta, A.; Visaria, S. Financing smallholder agriculture: An experiment with agent-intermediated microloans in India. J. Dev. Econ. 2017, 127, 306-337. [CrossRef]

27. Adjognon, S.G.; Liverpool-Tasie, L.S.O.; Reardon, T.A. Agricultural input credit in Sub-Saharan Africa: Telling myth from facts. Food Policy 2017, 67, 93-105. [CrossRef] [PubMed]

28. Beaman, L.; Karlan, D.; Thuysbaert, B.; Udry, C. Selection into Credit Markets: Evidence from Agriculture in Mali; Northwestern University: Evanston, IL, USA, 2015.

29. Lacalle-Calderon, M.; Perez-Trujillo, M.; Neira, I. Does microfinance reduce poverty among the poorest? A macro quantile regression approach. Dev. Econ. 2018, 56, 51-65. [CrossRef]

30. Jalilian, H.; Kirkpatrick, C. Financial development and poverty reduction in developing countries. Int. J. Financ. Econ. 2002, 7, 97-108. [CrossRef]

31. Khandker, S.R. Microfinance and poverty: Evidence using panel data from Bangladesh. World Bank Econ. Rev. 2005, 19, 263-286. [CrossRef]

32. Imai, K.S.; Arun, T.; Annim, S.K. Microfinance and household poverty reduction: New evidence from India. World Dev. 2010, 38, 1760-1774. [CrossRef]

33. Imai, K.S.; Gaiha, R.; Thapa, G. Is the millennium development goal of poverty still achievable? Role of institutions, finance and openness. Oxf. Dev. Stud. 2010, 38, 309-337. [CrossRef]

34. Imai, K.S.; Azam, M.D. Does microfinance reduce poverty in Bangladesh? new evidence from household panel data. J. Dev. Stud. 2012, 48, 633-653. [CrossRef]

35. Hassan, A.; Choudhury, M.A. The challenge in poverty alleviation: Role of islamic microfinance and social capital. Humanomics 2014, 30, 76-90. [CrossRef]

36. Malki, I. Microfinance and household poverty reduction: Empirical evidence from rural Pakistan. Oxf. Dev. Stud. 2015, 43, 84-104. [CrossRef]

37. Samer, S.; Majid, I.; Rizal, S.; Muhamad, M.R.; Sarah-Halim Rashid, N. The impact of microfinance on poverty reduction: Empirical evidence from Malaysian perspective. Procedia Soc. Behav. Sci. 2015, 195, 721-728. [CrossRef]

38. Miled, K.B.H.; Rejeb, J.E.B. Can microfinance help to reduce poverty? A review of evidence for developing countries. J. Knowl. Econ. 2016, 1-23. [CrossRef]

39. Khandker, S.R. Fighting Poverty with Microcredit: Experience in Bangladesh; Oxford University Press: Oxford, UK, 1998.

40. Wright, G.A.N. Microfinance Systems: Designing Quality Financial Services for the Poor; Zed Books Ltd.: London, UK; New York, NY, USA; The University Press Limited: Dhaka, Bangladesh, 2000.

41. Geda, A.; Shimeles, A.; Zerfu, D. Finance and poverty in Ethiopia: A household-level analysis. Wider Work. Pap. 2006. [CrossRef]

42. Swain, R.B.; Floro, M. Assessing the effect of microfinance on vulnerability and poverty among low income households. J. Dev. Stud. 2012, 48, 605-618. [CrossRef]

43. Nukpezah, J.A.; Blankson, C. Microfinance intervention in poverty reduction: A study of women farmer-entrepreneurs in rural Ghana. J. Afr. Bus. 2017, 18, 1-19. [CrossRef]

44. McCulloch, N.; Baulch, B. Simulating the impact of policy upon chronic and transitory poverty in rural Pakistan. Econometrics 2000, 36, 440-445.

45. Kiiru, J.; Machakos, K. The I Mpact of Microfinance on Rural Poor Households' Income and Vulnerability to Poverty: Case Study of Makueni District, Kenya. Unpublished Ph.D. Thesis, University of Bonn, Bonn, Germany, 2005. 
46. Swain, R.B.; Sanh, N.V.; Tuan, V.V. Microfinance and poverty reduction in the Mekong delta in Vietnam. Afr. Asian Stud. 2008, 7, 191-215. [CrossRef]

47. Wagner, C.; Winkler, A. The vulnerability of microfinance to financial turmoil—Evidence from the global financial crisis. World Dev. 2013, 51, 71-90. [CrossRef]

48. Almamun, A.; Mazumder, M.N.H. Impact of microcredit on income, poverty, and economic vulnerability in peninsular Malaysia. Dev. Pract. 2015, 25, 333-346. [CrossRef]

49. Lensink, R.; Servin, R.; Berg, M. Do savings and credit institutions reduce vulnerability? New evidence from Mexico. Rev. Income Wealth 2017, 63, 335-352. [CrossRef]

50. Abate, G.T.; Rashid, S.; Borzaga, C.; Getnet, K. Rural finance and agricultural technology adoption in Ethiopia: Does the institutional design of lending organizations matter? World Dev. 2016, 84, 235-253. [CrossRef]

51. Montgomery, J.W.H. Great expectations: Microfinance and poverty reduction in Asia and Latin America. Oxf. Dev. Stud. 2005, 33, 391-416.

52. Devi, L.Y. Rural Bank Development and Poverty Reduction in Indonesia: Evidence from Panel Co-Integration and Causality Tests. Causal Inference in Econometrics; Springer International Publishing: Cham, Switzerland, 2016; pp. 621-635.

53. Donou-Adonsou, F.; Sylwester, K. Financial development and poverty reduction in developing countries: New evidence from banks and microfinance institutions. Rev. Dev. Financ. 2016, 6, 82-90. [CrossRef]

54. Ali, I.; Hatta, Z.A.; Azman, A.; Islam, S. Microfinance as a development and poverty alleviation tool in rural Bangladesh: A critical assessment. Asian Soc. Work Policy Rev. 2017, 11, 4-15. [CrossRef]

55. Boateng, G.O.; Boateng, A.A.; Bampoe, H.S. Microfinance and poverty reduction in Ghana: Evidence from policy beneficiaries. Rev. Bus. Financ. Stud. 2015, 6, 99-108.

56. Wang, X.; Wang, D.; Wen, T. Effect of poverty reduction and income growth about loan for rural residents in china. J. Quant. Tech. Econ. 2014, 31, 40-55.

57. Schultz, T.W. Transforming Traditional Agriculture; Yale University Press: New Haven, CT, USA, 1964.

58. Popkin, S.L.; Popkin, S.L. The Rational Farmer: The Political Economy of Rural Society in Vietnam; University of California Press: Berkeley, CA, USA, 1979.

59. Chayanov, A.V. The Theory of Farmer Economy; University of Wisconsin Press: Madison, WI, USA.

60. Polanyi, K.; Arensberg, C.M.; Pearson, H.W. (Eds.) Trade and Market in the Early Empires: Economies in History and Theory; Free Press: New York, NY, USA, 1965.

61. Scott James, C. The Moral Economy of the Farmer: Rebellion and Subsistence in South East Asia; Yale University Press: New Haven, CT, USA; London, UK, 1976.

62. Banerjee, A.V.; Newman, A.F. Occupational choice and the process of development. J. Political Econ. 1993, 101, 274-298. [CrossRef]

63. Galor, O.; Zeira, J. Income distribution and macroeconomics. Rev. Econ. Stud. 1993, 60, 35-52. [CrossRef]

64. Aghion, P.; Howitt, P.W. The Economics of Growth.; MIT Press: Cambridge, MA, USA, 2009.

65. National Bureau of Statistics of China. China's Regional Economic Statistical Yearbook 2011; China Statistic Press: Beijing, China, 2012.

66. National Bureau of Statistics of China. China County (City) Social Economic Statistical Yearbook 2011; China Statistic Press: Beijing, China, 2011.

67. Koenker, R.; Bassett, G., Jr. Regression quantiles. Econ. J. Econom. Soc. 1978, 46, 33-50. [CrossRef]

(c) 2018 by the authors. Licensee MDPI, Basel, Switzerland. This article is an open access article distributed under the terms and conditions of the Creative Commons Attribution (CC BY) license (http://creativecommons.org/licenses/by/4.0/). 